\title{
Thyrotoxicosis and Adrenocortical Hormone Deficiency During Immune-checkpoint Inhibitor Treatment for Malignant Melanoma
}

\author{
HIROYUKI ARIYASU ${ }^{1}$, HIDEFUMI INABA ${ }^{1}$, TAKAYUKI OTA ${ }^{1}$, HIROYUKI YAMAOKA ${ }^{1}$, YASUSHI FURUKAWA ${ }^{1}$, \\ HIROSHI IWAKURA $^{1}$, NAOTAKA DOI ${ }^{2}$, YUKI YAMAMOTO ${ }^{2}$ and TAKASHI AKAMIZU ${ }^{1}$ \\ ${ }^{1}$ The First Department of Medicine, ${ }^{2}$ Department of Dermatology, \\ Wakayama Medical University, Wakayama, Japan
}

\begin{abstract}
Background: Immune-checkpoint inhibitors (ICIs) are novel promising agents for the treatment of malignant tumors. However, critical endocrine immune-related adverse events (irAEs) by ICIs often occur. Case report: A 63-year-old woman with advanced malignant melanoma had received antiPD-1 antibody (nivolumab, $2 \mathrm{mg} / \mathrm{kg}$ every 3 weeks) for 8 cycles (from day 0 to day 147). On day 168, nivolumab was switched to anti-CTLA-4 antibody (ipilimumab, $3 \mathrm{mg} / \mathrm{kg}$ every 3 weeks). Twenty-eight days later, she was diagnosed with thyrotoxicosis due to painless thyroiditis (day 196). Thirty-five days later (day 231), thyrotoxicosis turned to hypothyroidism. In addition, twenty-five days later (day 256), she was diagnosed with adrenocortical insufficiency due to adrenocortical hormone (ACTH) deficiency. Hormone replacements with levothyroxine and hydrocortisone were administered. She showed eosinophilia, ESR/CRP/LDH elevation, liver dysfunction and hyponatremia before diagnosis of ACTH insufficiency. Eosinophilia, thrombocytopenia, ESR/CRP/LDH elevation, and liver dysfunction might be important for early detection of thyrotoxicosis in our case. Conclusion: The present report provides the first detailed presentation of combined thyrotoxicosis and isolated ACTH deficiency induced by ICIs. Since rapidly progressive fatal endocrine system failure may be provoked during ICI therapy, precise diagnosis and prompt treatment as well as close follow-up is critical. We propose routine monitoring of endocrine functions and related symptoms
\end{abstract}

This article is freely accessible online.

Correspondence to: Hidefumi Inaba, The First Department of Medicine, Wakayama Medical University, 811-1, Kimiidera, Wakayama, Japan. Tel: +81 734410625, Fax: +81 734459436, e-mail: inaba@wakayama-med.ac.jp

Key Words: PD-1, CTLA-4, malignant melanoma, ACTH, pituitary gland, thyroid gland, irAEs. (worsened fatigue, hypoglycemia, hypotension or hyponatremia), as well as other laboratory tests during ICI therapy.

Major components of the immune checkpoints are the cytotoxic T-lymphocyte associated antigen 4 (CTLA-4) and the programmed death protein 1 (PD-1). CTLA-4 is located on the surface of activated T-cells, therefore inhibiting binding of CD28 to B7 molecule on antigen presenting cells (1). The CTLA-4 pathway predominantly acts in lymph nodes. PD-1 is mainly expressed on T-cells (2). The PD-1 pathway is involved with tumor microenvironment.

Monoclonal antibodies to these molecules are referred to as immuno-checkpoint inhibitors (ICIs), and are currently novel promising agents in the treatment for malignant tumors including malignant melanoma $(1,2)$. On the other hand, various adverse events in multiple organs are reported as immune-related adverse events (irAEs) (1-3). irAEs in pituitary glands, thyroid glands, adrenal glands, and type 1 diabetes mellitus have been reported $(3,4)$. However, the mechanism by which ICIs cause irAEs remains unclear. A 63-year-old woman with malignant melanoma received antiPD-1 antibody, then switched to anti-CTLA-4 antibody. She developed painless thyroiditis, followed by adrenocortical hormone $(\mathrm{ACTH})$ deficiency. To date, few reports have mentioned endocrine irAEs in detail, and precise management of endocrine irAEs is complicated. This case (report) highlights possible mechanisms of irAEs and offers appropriate screening, diagnosis, and follow-up strategies during ICI therapy.

\section{Case}

Patients with malignant melanoma treated with ICIs in our hospital from September 2014 to October 2017 were examined. A total of 32 patients received anti-PD-1 therapy and 6 patients among them received combination treatment with anti-CTLA-4. Of those, a 63-year-old woman developed 


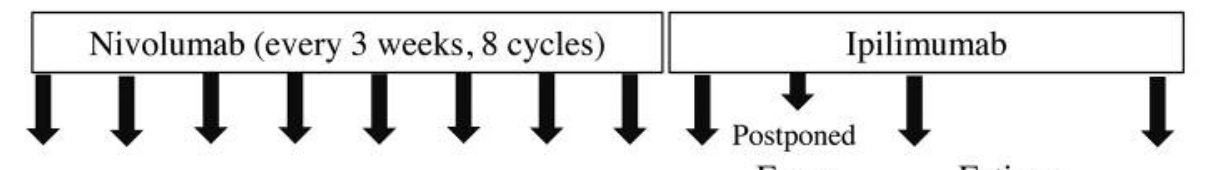

Fever,

Fatigue,
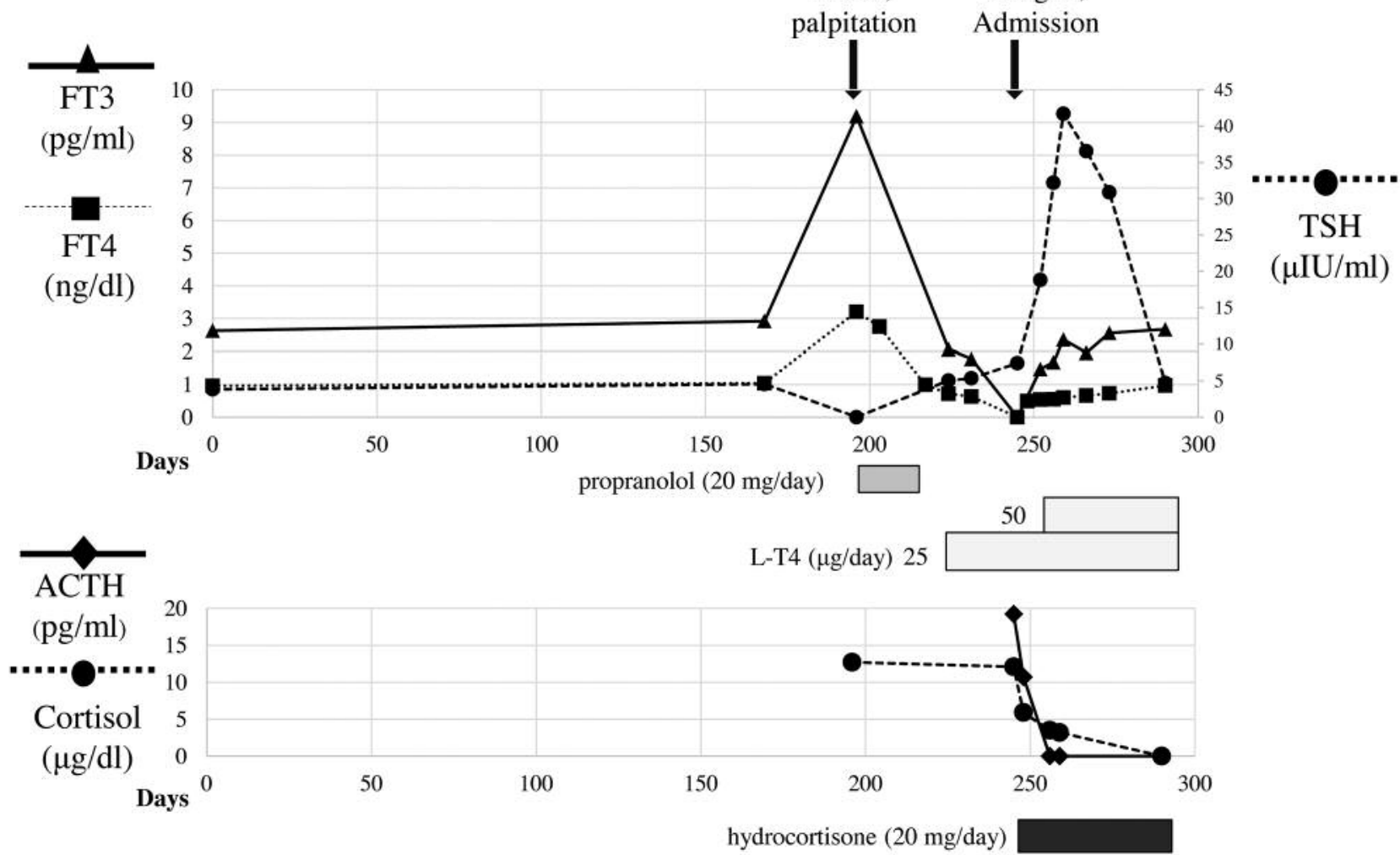

Figure 1. Clinical course after initiation of nivolumab. One-hundred ninety-six days after nivolumab therapy (twenty-eight days after switching to ipilimumab), thyrotoxicosis was seen. On day 231, hypothyroidism was seen, and on day 256, adrenocortical hormone deficiency was diagnosed.

current endocrine irAE. She was diagnosed as malignant melanoma in genital area 2 years before (stage III Bp, T3bN1aM0). She underwent surgery, and received adjuvant chemoimmunotherapy with 6 courses of DAV-feron therapy (consisting of dacarbazine, nimustine hydrochloride, vincristine, and interferon-beta) and a monthly local injection of interferon beta 8 times. Due to the metastases of the disease, anti-PD-1 antibody (nivolumab, $2 \mathrm{mg} / \mathrm{kg}$ every 3 weeks) therapy was started, and 8 cycles of treatment were carried out (Figure 1, Table I). Thyroid function had been normal during therapy. Because of disease progression, nivolumab was changed to anti-CTLA-4 antibody (ipilimumab, $3 \mathrm{mg} / \mathrm{kg}$ every 3 weeks) 168 days after nivolumab initiation. Seven days later (day 175), her laboratory data showed eosinophilia; Eosinophil 13.8\%, $590 / \mu 1$, and thrombocytopenia; $11.8 \times 10^{4} \mu \mathrm{l}$ (Table I). Fourteen days later (day 189), she developed general fatigue and fever up to $38.0^{\circ} \mathrm{C}$, with deterioration of thrombocytopenia; $9.9 \times 10^{4} \mu \mathrm{l}$, increase of CRP; $1.58 \mathrm{mg} / \mathrm{dl}$ and erythrocyte sedimentation rate (ESR); $29 \mathrm{~mm} / 1 \mathrm{~h}$. Mild liver dysfunction and LDH elevation were also observed. Therefore, ipilimumab treatment was postponed. On day 192, exacerbation of thrombocytopenia and increase of CRP were seen. On day 196, she had palpitation, and visited our hospital. In laboratory tests, thyrotoxicosis was observed (Tables I and II), and she was referred to endocrine department. She had been treated with essential hypertension for 20 years. Other past history was unremarkable. She did not have familial history associated with autoimmune diseases. Her body height was $150 \mathrm{~cm}$, and her weight was $61.3 \mathrm{~kg}$ (BMI, $27.1 \mathrm{~kg} / \mathrm{m}^{2}$ ). Her blood pressure was 148/81 $\mathrm{mmHg}$, her heart rate (HR) was 107 beats /min and regular and her body temperature was $36.3^{\circ} \mathrm{C}$. No exophthalmos was observed. No finger tremor was seen. Her thyroid gland was firm, not enlarged with no tenderness. No abnormal heart or lung sounds were detected. In the laboratory test (Table II), 
Table I. Clinical course and findings in laboratory data of the patient.

\begin{tabular}{|c|c|c|c|c|c|c|c|c|c|c|c|}
\hline Days & $\begin{array}{c}0 \\
\text { Nivo \#1 }\end{array}$ & $\begin{array}{c}168 \\
\text { Ipi \#1 }\end{array}$ & 175 & $\begin{array}{c}189 \\
\text { Postpone Ipi }\end{array}$ & 192 & $\begin{array}{c}196 \\
\text { Referral to } \\
\text { endocrine } \\
\text { department }\end{array}$ & $\begin{array}{c}224 \\
\text { Ipi \#2 }\end{array}$ & 231 & $\begin{array}{c}245 \\
\text { Admission }\end{array}$ & 248 & 256 \\
\hline Assesment & & & $\begin{array}{l}\text { Eosinophilia } \\
\text { thrombo- } \\
\text { cytopenia }\end{array}$ & $\begin{array}{c}\text { Liver } \\
\text { dysfunction } \\
\text { CRP/ESR } \\
\text { elevation }\end{array}$ & & Thyrotoxicosis & $\begin{array}{l}\text { Eosinophilia } \\
\text { ESR } \\
\text { elevation }\end{array}$ & $\begin{array}{c}\text { Hypothyroid } \\
\text { CRP } \\
\text { elevation }\end{array}$ & $\begin{array}{c}\text { Liver } \\
\text { dysfunction }\end{array}$ & $\begin{array}{l}\text { Adrenal } \\
\text { failure } \\
\text { suspected }\end{array}$ & $\begin{array}{c}\text { Adrenal } \\
\text { failure } \\
\text { confirmed }\end{array}$ \\
\hline $\begin{array}{l}\text { Objective } \\
\text { Symptom }\end{array}$ & & & & $\begin{array}{c}\text { fever up } \\
38^{\circ} \mathrm{C}\end{array}$ & & $\begin{array}{c}148 / 81 \mathrm{mmHg} \\
\text { HR } 107 / \mathrm{min} \\
\text { palpitation }\end{array}$ & & & $\begin{array}{c}120 / 80 \mathrm{mmHg} \\
\text { HR } 88 / \mathrm{min} \\
\text { fatigue }\end{array}$ & & \\
\hline FT3 pg/ml & 2,63 & 2,92 & ND & ND & ND & 9,19 & 2,07 & 1,78 & $<1.00$ & ND & 1,68 \\
\hline FT4 ng/dl & 0,96 & 1,04 & ND & ND & ND & 3,21 & 0,72 & 0,63 & $<0.40$ & ND & $\mathbf{0 , 5 5}$ \\
\hline $\mathrm{TSH} \mu \mathrm{IU} / \mathrm{ml}$ & 3,846 & 4,57 & ND & ND & ND & 0,018 & 5,046 & 5,352 & 7,434 & ND & 32,204 \\
\hline ACTH pg/ml & ND & ND & ND & ND & ND & ND & ND & ND & 19,2 & 10,7 & $<1.0$ \\
\hline Cortisol $\mu \mathrm{g} / \mathrm{dl}$ & ND & ND & ND & ND & ND & 12,7 & ND & ND & 12,1 & $\mathbf{5 , 9}$ & 3,5 \\
\hline $\mathrm{WBC} / \mu \mathrm{l}$ & 3800 & 4470 & 4260 & 4450 & 4450 & 3750 & 5650 & 7450 & 5810 & 6390 & 7210 \\
\hline Eos $\%$ & 2,9 & 8,1 & 13,8 & 5,6 & 4 & 5,6 & 14 & 26 & 2 & 4,1 & 2,1 \\
\hline $\mathrm{EOS} / \mu \mathrm{l}$ & 110 & 360 & 590 & 250 & 154 & 210 & 791 & 1937 & 116 & 261 & 150 \\
\hline Plt $\times 10^{4} / \mu \mathrm{l}$ & 13,3 & 15,7 & 11,8 & $\mathbf{9 , 9}$ & 8,8 & 8,9 & 17,1 & 14,6 & 13,3 & 13,4 & 13,1 \\
\hline $\mathrm{Na}$ mEq/1 & 145 & 142 & 142 & 141 & 141 & 144 & 141 & 141 & 138 & 136 & 137 \\
\hline AST IU/1 & 22 & 17 & 22 & 59 & 35 & 29 & 18 & 17 & 39 & 72 & 43 \\
\hline ALT IU/1 & 16 & 12 & 15 & 49 & 56 & 40 & 13 & 12 & 31 & 67 & 52 \\
\hline LDH IU/1 & 187 & 202 & 221 & 350 & 393 & 333 & 209 & 248 & 359 & 406 & 415 \\
\hline CRP mg/dl & 0,03 & 0,04 & 0,15 & 1,58 & 3,79 & 1,63 & 0,04 & $\mathbf{0 , 3 9}$ & 3,43 & 5,78 & ND \\
\hline ESR mm/1h & 11 & ND & ND & 29 & ND & ND & 21 & ND & 45 & ND & ND \\
\hline Treatment & & & & & & $\begin{array}{l}\text { Propranorol } \\
\quad 20 \mathrm{mg}\end{array}$ & & L-T4 $25 \mu \mathrm{g}$ & & $\begin{array}{l}\mathrm{L}-\mathrm{T} 450 \mu \mathrm{g} \\
\text { ydrocortison } \\
\quad 20 \mathrm{mg}\end{array}$ & \\
\hline
\end{tabular}

Bold letter denotes abnormal value. Days: days after nivolumab initiation; nivo: nivolumab; Ipi: ipilimumab; Eos: eosinophils proportion; EOS: eosinophil counts; TSH: thyrotropin; FT3: triiodothyronine; FT4: thyroxine; ACTH: adrenocorticotropic hormone; ESR: erythrocyte sedimentation rate; ND: not determined.

serum FT3 (9.19 pg/ml: normal range 1.71-3.71) and FT4 $(3.21 \mathrm{ng} / \mathrm{dl}: 0.70-1.55)$ levels were increased, concomitant with suppressed TSH levels (0.018 $\mu \mathrm{IU} / \mathrm{ml}: 0.35-4.94)$. TRAb (anti-TSH receptor antibody) and TPOAb were negative. Anti-Tg (thyroglobulin) antibody was positive, $40.4 \mathrm{IU} / \mathrm{ml}$ $(<28.0)$. Serum $\mathrm{Tg}$ level was elevated to $1903.0 \mathrm{ng} / \mathrm{ml}$ $(<30.0)$. Serum cortisol level was normal, $12.7 \mu \mathrm{g} / \mathrm{dl}(2.9-$ 19.4). On an ultrasonographic examination, her thyroid gland was normal in size, and Doppler blood flow was not increased (Figure 2A). Based on these findings, she was diagnosed as painless thyroiditis. Propranolol; $20 \mathrm{mg}$ /day was prescribed. Her thyroid function was spontaneously recovered with other laboratory data improved, thus propranolol was ceased, and second ipilimumab infusion was carried out (day 224). Seven days later, eosinophilia progressed, and CRP/LDH was slightly increased (day 231). Due to the hypothyroidism (FT3 $1.78 \mathrm{pg} / \mathrm{ml}$, FT4 $0.63 \mathrm{ng} / \mathrm{dl}$, and TSH $5.352 \mu \mathrm{IU} / \mathrm{ml}$ ), L-T4; $25 \mu \mathrm{g} / \mathrm{day}$ was started. Seventy-seven days after ipilimumab initiation (day 245), she developed severe fatigue, and was admitted. Laboratory tests (Table III) showed worsened hypothyroidism: decreased serum FT3, $<1.00 \mathrm{pg} / \mathrm{ml}$ and FT4, $<0.40 \mathrm{ng} / \mathrm{dl}$, and increased serum TSH level, $7.434 \mu \mathrm{IU} / \mathrm{ml}$. Mild liver dysfunction and CRP/ESR/LDH elevation were also observed. Subnormal hyponatremia; $138 \mathrm{mEq} / \mathrm{L}$ was seen. On an ultrasonographic examination, her thyroid gland volume was slightly decreased, and thyroid internal intensity was lowered compared to the previous result at first visit (Figure 2B). Her serum cortisol level of $12.1 \mu \mathrm{g} / \mathrm{dl}$ (2.9-19.4) and plasma ACTH level, $19.2 \mathrm{pg} / \mathrm{mL}$ (7.2-63.3) were within normal range. Posterior pituitary functions were preserved. Pituitary MRI showed no remarkable abnormalities (Figure 3). In an ACTH stimulation test, response of cortisol was preserved (Figure 4A). Three days after the admission (day 248), her serum cortisol level of $5.9 \mu \mathrm{g} / \mathrm{dl}$ and plasma ACTH level, $10.7 \mathrm{pg} / \mathrm{ml}$, both decreased compared to those at admission. In pituitary provocation tests with $\mathrm{CRH}$ and $\mathrm{GnRH}$ (Gonadotropin releasing hormone) stimulation, LH and FSH responses were preserved with mild delay, but ACTH and cortisol responses were remarkably attenuated (Figure 4B). 

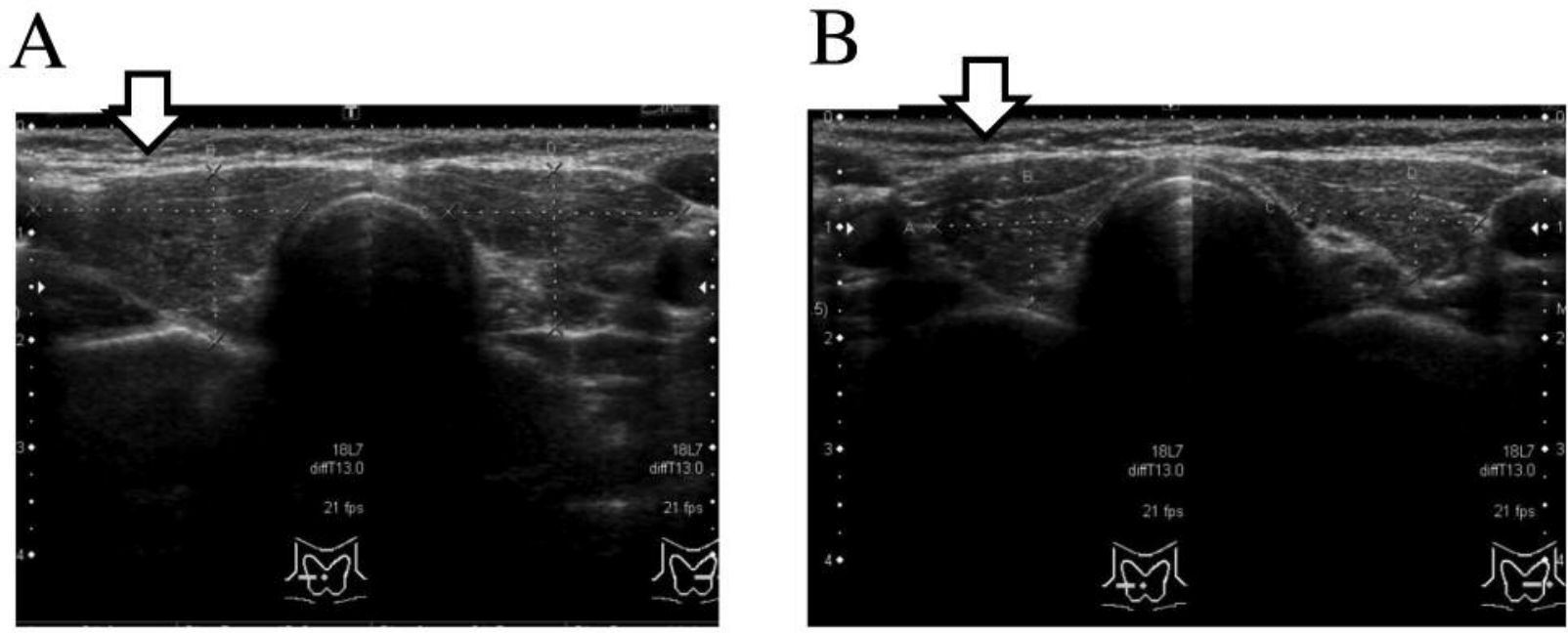

Figure 2. Ultrasonographic examinations on thyroid. On first visit, thyroid size was normal, and Doppler blood flow was not increased (A, arrow). On admission, thyroid volume was slightly decreased, and thyroid internal intensity was lowered (B, arrow).

TRH test was not conducted, because the patient had thyroiditis. GH (growth hormone) response to GHRP-2 (growth hormone releasing peptide-2) was normal (Figure 4C). These results were compatible with severe secondary adrenocortical insufficiency due to ACTH deficiency. L-T4 dose was increased to $50 \mu \mathrm{g} / \mathrm{day}$ and hydrocortisone (20 mg/day) treatments were started, and both, her symptoms and laboratory data improved (day 256). In spite of third ipilimumab therapy and additional one nivolumab infusion, she was passed away due to progression of the disease 380 days after initial ICI therapy at her home.

\section{Discussion}

In the current case, discontinuation of nivolumab and initiation of ipilimumab induced both thyroid and pituitary dysfunction. Thyroid function had been normal during long nivolumab treatment, however, 28 days after ipilimumab treatment, thyrotoxicosis due to painless thyroiditis with $\mathrm{Tg}$ and $\mathrm{TgAb}$ elevation occurred. Although the thyroid dysfunction was seemed to be associated with ipilimumab, it is more likely due to nivolumab treatment rather than ipilimumab, referring the time of onset and the frequency of thyroid disorder observed with PD-1 inhibitors (3). As is often seen in cases of painless thyroiditis (5), the thyroid function turned to hypothyroidism 63 days after ipilimumab initiation. Adrenal function seemed to be normal on admission, and was progressively depleted in couple of days. The secondary adrenocortical insufficiency was distinguished from primary adrenocortical insufficiency with intact reaction of cortisol in ACTH stimulation test (Figure 4A) and

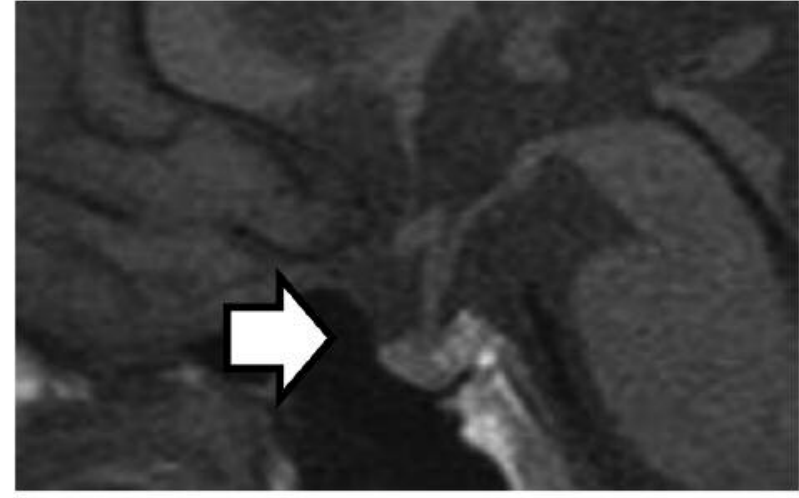

Figure 3. A T1-weighed sagittal image of pituitary MRI on admission. No remarkable abnormalities in the pituitary gland (arrow) were observed.

deteriorated response of $\mathrm{ACTH}$ in $\mathrm{CRH}$ provocation test (Figure 4B). The prevalence of adrenal insufficiency by nivolumab was $3.13 \%(1 / 32)$ in our hospital, similar to the prevalence in other hospitals (6), and high prevalence of those with anti-CTLA-4 treatment; $16.7 \%$ (1/6) was seen in our cohort.

A case of hypopituitarism and hypothyroidism (7) or another case of hypothyroidism and isolated ACTH deficiency (8) during nivolumab treatment have been reported, however, thyrotoxicosis followed by insolated ACTH deficiency has not been reported. A case with thyrotoxicosis and adrenocortical hormone deficiency has not been reported before, as our knowledge. As is seen in this 
Table II. Laboratory data at referral to endocrine department.

\begin{tabular}{|c|c|c|c|}
\hline $\begin{array}{l}\text { WBC } \\
(\text { Eos } 5.6 \%)\end{array}$ & $3750 / \mu 1(3300-8600)$ & PG & $\begin{array}{c}108 \mathrm{mg} / \mathrm{dl} \\
\mathrm{HbA} 1 \mathrm{c} 5.7 \%\end{array}$ \\
\hline $\mathrm{Hb}$ & $12,3 \mathrm{~g} / \mathrm{dl}(11.6-14.8)$ & ANA & $\times 40(<40)$ \\
\hline Plt & $\underline{8.9 \times 10^{4}} \underline{4} \mu \underline{\mu l(15.8-34.8)}$ & $\mathrm{C} 3$ & $120 \mathrm{mg} / \mathrm{dl}(65-135)$ \\
\hline AST & $29 \mathrm{IU} / 1(13-30)$ & $\mathrm{C} 4$ & $35 \mathrm{mg} / \mathrm{dl}(13-35)$ \\
\hline ALT & $40 \mathrm{IU} / 1(7-23)$ & CH50 & $47 \mathrm{U} / \mathrm{ml}(30-50)$ \\
\hline ALP & $336 \mathrm{IU} / 1(106-322)$ & KL-6 & $444 \mathrm{U} / \mathrm{ml}(<500)$ \\
\hline LDH & $\underline{333 \mathrm{IU} / 1(124-222)}$ & SP-A & $35.1 \mathrm{ng} / \mathrm{ml}(<43.8)$ \\
\hline BUN & $16 \mathrm{mg} / \mathrm{dl}(8-20)$ & SP-D & $31.5 \mathrm{ng} / \mathrm{ml}(<110)$ \\
\hline $\mathrm{Cr}$ & $0.53 \mathrm{mg} / \mathrm{dl}(0.48-0.79)$ & $\mathrm{TSH}$ & $\underline{0,018 \mu \mathrm{IU} / \mathrm{ml}(0.35-4.94)}$ \\
\hline T-bil & $0,6 \mathrm{mg} / \mathrm{dl}(0.4-1.5)$ & FT3 & $9.19 \mathrm{pg} / \mathrm{ml}(1.71-3.71)$ \\
\hline $\mathrm{Na}$ & $144 \mathrm{mEq} / 1$ (139-145) & FT4 & $\underline{3.21 \mathrm{ng} / \mathrm{dl}(0.70-1.55)}$ \\
\hline K & $\underline{3,4 \mathrm{mEq} / 1(3.6-4.8)}$ & TRAb-3 & $<1.0 \mathrm{IU} / \mathrm{ml}(<2.0)$ \\
\hline $\mathrm{Cl}$ & $112 \mathrm{mEq} / 1(101-108)$ & $\mathrm{TgAb}$ & $40.4 \mathrm{IU} / \mathrm{ml}(<28.0)$ \\
\hline CRP & $1.63 \mathrm{mg} / \mathrm{dl}(<0.30)$ & TPOAb & $9.1 \mathrm{U} / \mathrm{ml}(<16.0)$ \\
\hline Urinary analysis & & $\mathrm{Tg}$ & $1903 \mathrm{ng} / \mathrm{ml}(<30.0)$ \\
\hline SG & 1.022 & Cortisol & $12.7 \mu \mathrm{g} / \mathrm{dl}(2.9-19.4)$ \\
\hline Protein & $(-)$ & АCTH & $\mathrm{ND} \mathrm{pg} / \mathrm{ml}(7.2-63.3)$ \\
\hline Occult blood & $(+/-)$ & & \\
\hline Sugar & $(-)(-)$ & & \\
\hline
\end{tabular}

Underline denote abnormal values. PG: Plasma glucose; ANA: anti-nuclear antibody; TSH: thyrotropin; FT3: triiodothyronine; FT4: thyroxine; TRAb-3: TSH receptor antibody (third generation); TgAb: anti-thyroglobulin antibody; TPOAb: anti-thyroid peroxidase antibody; Tg: thyroglobulin; ACTH: adrenocorticotropic hormone; ND: not determined.

Table III. Laboratory data on admission.

\begin{tabular}{|c|c|c|c|}
\hline WBC & $5810 / \mu 1(3300-8600)$ & TSH & 7.434 $\mu \mathrm{IU} / \mathrm{ml}(0.35-4.94)$ \\
\hline$(\operatorname{Eos} 2.1 \%)$ & & FT3 & $\leq 1.00 \mathrm{pg} / \mathrm{ml}(1.71-3.71)$ \\
\hline $\mathrm{Hb}$ & $12.6 \mathrm{~g} / \mathrm{dl}(11.6-14.8)$ & FT4 & $\leq 0.40 \mathrm{ng} / \mathrm{dl}(0.70-1.55)$ \\
\hline Plt & $13.3 \times 10^{4} / \mu \mathrm{l}(15.8-34.8)$ & $\operatorname{TgAb}$ & $37.3 \mathrm{IU} / \mathrm{ml}(<28.0)$ \\
\hline AST & $\underline{39 \mathrm{IU} / 1(13-30)}$ & TPOAb & $11.4 \mathrm{U} / \mathrm{ml}(<16.0)$ \\
\hline ALT & $31 \mathrm{IU} / 1(7-23)$ & $\mathrm{Tg}$ & $\underline{103 \mathrm{ng} / \mathrm{ml}(<30.0)}$ \\
\hline ALP & $337 \mathrm{IU} / 1$ (106-322) & Cortisol & $12.1 \mu \mathrm{g} / \mathrm{dl}(2.9-19.4)$ \\
\hline LDH & 359 IU/1 (124-222) & ACTH & $19.2 \mathrm{pg} / \mathrm{ml}(7.2-63.3)$ \\
\hline $\mathrm{Na}$ & $138 \mathrm{mEq} / 1(139-145)$ & GH & $1.3 \mathrm{ng} / \mathrm{ml}(0-2.1)$ \\
\hline K & $3.8 \mathrm{mEq} / 1(3.6-4.8)$ & IGF-I & $46 \mathrm{ng} / \mathrm{ml}(66-194)$ \\
\hline $\mathrm{Cl}$ & $106 \mathrm{mEq} / 1$ (101-108) & LH & $6 . \overline{1 \mathrm{mIU} / \mathrm{ml}(1.7-11.2)}$ \\
\hline CRP & $3.43 \mathrm{mg} / \mathrm{dl}(<0.30)$ & FSH & $\underline{46.9 \mathrm{mIU} / \mathrm{ml}(2.1-18.6)}$ \\
\hline ESR & $45 \mathrm{~mm} / 1$ hour $(<15)$ & E2 & $11 \mathrm{pg} / \mathrm{ml}$ \\
\hline PG & $99 \mathrm{mg} / \mathrm{dl}$ & PRL & $24.5 \mathrm{ng} / \mathrm{ml}(<15)$ \\
\hline $\mathrm{HbAlc}$ & $5.7 \%$ & & \\
\hline
\end{tabular}

Underline denote abnormal values. ESR: Erythrocyte sedimentation rate; PG: plasma glucose; TSH: thyrotropin; FT3: triiodothyronine; FT4: thyroxine; $\mathrm{TgAb}$ : anti-thyroglobulin antibody; TPOAb: anti-thyroid peroxidase antibody; Tg: thyroglobulin; ACTH: Adrenocorticotropic hormone; GH: growth hormone; IGF-I: insulin-like growth factor-I; LH: luteinizing hormone; FSH: follicle stimulating hormone; E2: estradiol; PRL: prolactin.

case, irAEs in pituitary gland and thyroid gland may happen, but the prevalence was unknown (3). Since symptoms such as general fatigue and appetite loss are often seen in patients with malignant diseases, and also observed in those with pituitary and thyroid diseases, the diagnoses of those irAEs are more complicated. In contrast to idiopathic autoimmune hypophysitis only observed in 1 in 9 million individuals (9), the overall estimated prevalence of irAE-related pituitary dysfunction is $9.1 \%$ (3). Among pituitary dysfunctions, the incidence of secondary adrenocortical insufficiency, secondary hypothyroidism, and secondary hypogonadism were $6.1 \%, 7.6 \%$, and $7.5 \%$, respectively (3). Pituitary enlargement has been seen in irAE-related hypophysitis (10) similarly to cases of idiopathic autoimmune hypophysitis (9). 


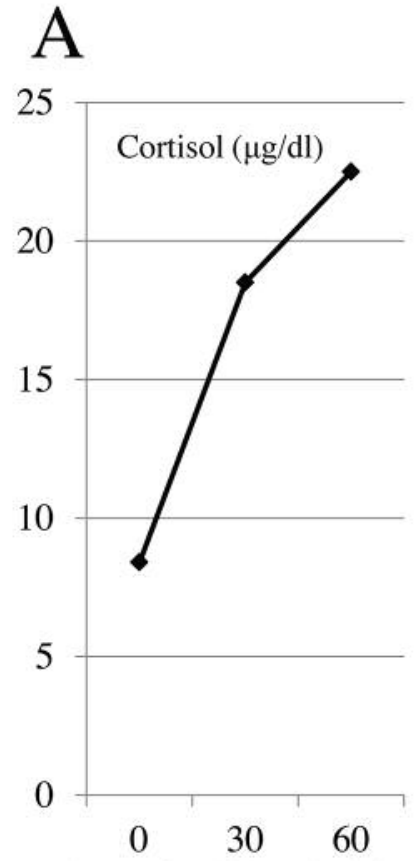

Minutes after ACTH stimulation
B

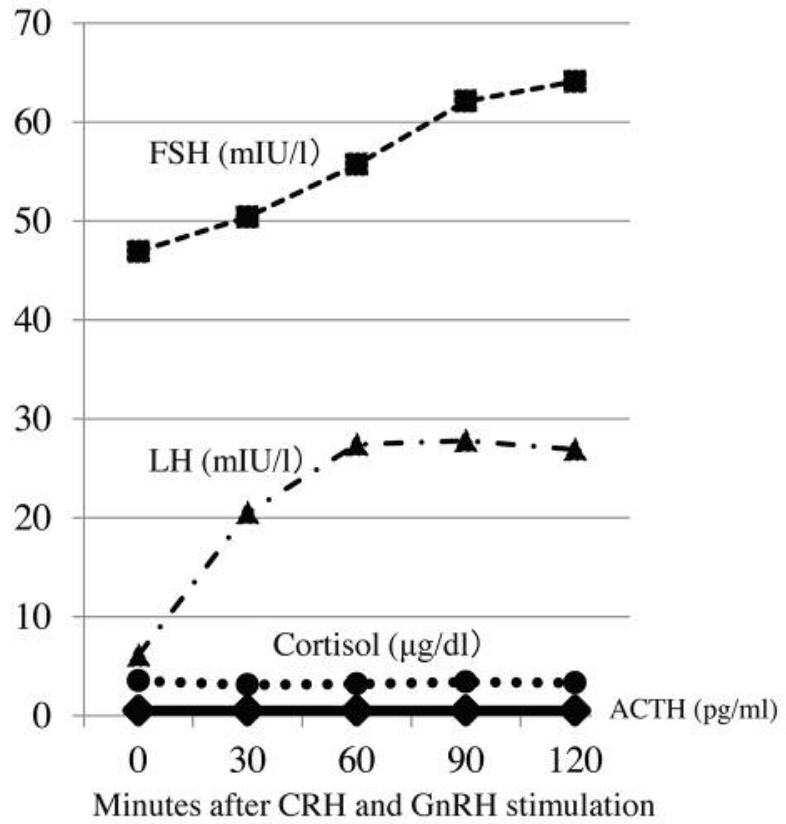

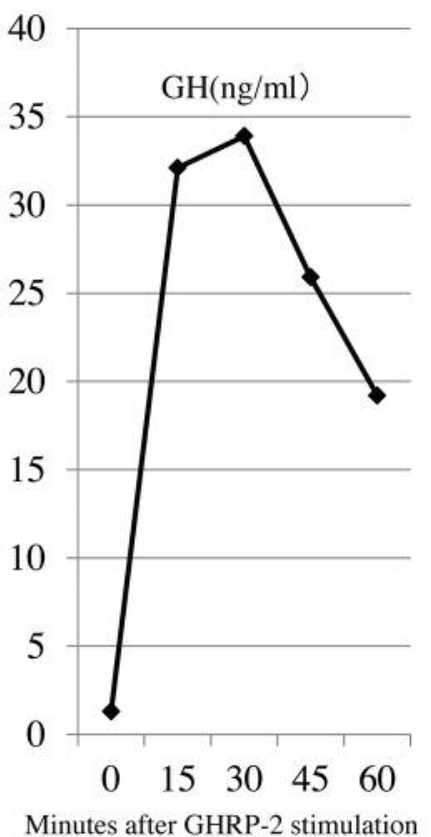

Figure 4. The results of pituitary provocation tests. A: An ACTH stimulation test showed normal cortisol response. B: CRH (ACTH stimulating hormone) and GnRH (Gonadotropin releasing hormone) stimulation test showed mildly delayed LH (luteinizing hormone) and FSH (follicular stimulating hormone) responses. ACTH and cortisol secretions are severely attenuated. C: A GHRP-2 (growth hormone releasing peptide-2) stimulation test showed intact GH (growth hormone) response.

Higher expression of CTLA-4 in the pituitary gland was reported to be related to severe hypophysitis, based on type II or type IV allergy by anti-CTLA-4 antibodies (11).

More important clinical entity is isolated ACTH deficiency (IAD), one of the fatal endocrine diseases characterized as pituitary ACTH insufficiency, possible autoimmune mechanism is involved accompanying other autoimmune diseases (12). In fact, thyroiditis and positivity of $\operatorname{TgAb}$ were observed in our case. Taken together, both Tg and ACTH-associated immunity in our case seemed to potentially be affected by nivolumab, and ipilimumab might induce dysfunctions in thyroid and ACTH. In IAD, pituitary abnormality was reported to be rarely seen at diagnosis, as was in a case of irAE-related ACTH deficiency (13), and also in our case. Cho et al. reported that hyponatremia can be a powerful predictor of the development of isolated ACTH deficiency with nivolumab (14), and our case also showed decrease of serum Na levels from $144 \mathrm{mEq} / 1$ to $138 \mathrm{mEq} / \mathrm{l}$ in advance of ACTH insufficiency. Ariyasu, et al reported that eosinophilia was observed more than a month before onset of adrenal failure in some cases (6). Our case showed both hyponatremia and eosinophilia before diagnosis of ACTH insufficiency. In addition, ESR/CRP/LDH elevation and liver dysfunction might be important for early investigation for adrenal failure. Thyrotoxicosis might also have accelerated adrenal insufficiency in the case.

In contrast to pituitary gland, thyroid gland is easily affected by anti-PD-1 antibody rather than anti-CTLA-4 antibody, and transient thyrotoxicosis may precede hypothyroidism (3). Yamauchi et al. reported 5 cases with nivolumab-induced thyroiditis, and proposed possible relation of PD-L1 and PD-L2 expressions on thyroid gland to irAE (15). Prevalence of hypothyroidism was 5.9\%, and hyperthyroidism was recorded in $1-4.7 \%$ of patients with anti-PD-1 treatment (3). Eosinophilia, thrombocytopenia, ESR/CRP/LDH elevation and liver dysfunction might be important for early detection for thyrotoxicosis in our case.

Both $\mathrm{Tg}$ and ACTH-associated immunity in our case seemed to be potentially affected by nivolumab, and ipilimumab might promote dysfunctions in thyroid and ACTH-producing cells. In certain genetic and environment backgrounds, ICI may activate immunoreactivities especially including autoreactive cytotoxic $\mathrm{CD}^{+} \mathrm{T}$-cell directing to endocrine organs $(1,2)$. In our case, upon activation of anti$\mathrm{Tg}$ and possibly anti-ACTH immunity with cross presentation of melanoma antigen, exacerbation of thyroiditis and deterioration of ACTH secretion might be seen. 
Bowyer et al. reported that in $35 \%$ of patients with melanoma who received anti-CTLA-4 antibody after discontinuation of anti-PD-1 antibody, grade 3-4 irAEs were developed (16). They report clinical benefits of a sequential administration of nivolumab followed by ipilimumab in patients with advanced melanoma, albeit associated with a higher frequency of adverse events. Gebhardt et al. reported that an early increase in eosinophils during the treatment with ipilimumab was associated with preferable clinical response (17).

In conclusion, both pituitary and thyroid dysfunction developed after nivolumab switching to ipilimumab therapy in the current case. Since fatal endocrine systems failure may occur during ICI treatment, precise diagnosis and routine follow-up is critical. In cases where any symptom is observed, closer monitoring of thyroid and pituitary function is necessary. Further investigations with a greater number of cases during longer periods are warranted to establish diagnostic and therapeutic approaches to irAEs. Prediction of individuals who are susceptible to irAEs is also necessary.

\section{References}

1 Hodi FS, O'Day SJ, McDermott DF, Weber RW, Sosman JA, Haanen JB, Gonzalez R, Robert C, Schadendorf D, Hassel JC, Akerley W, van den Eertwegh AJ, Lutzky J, Lorigan P, Vaubel JM, Linette GP, Hogg D, Ottensmeier CH, Lebbé C, Peschel C, Quirt I, Clark JI, Wolchok JD, Weber JS, Tian J, Yellin MJ, Nichol GM, Hoos A and Urba WJ: Improved survival with ipilimumab in patients with metastatic melanoma. N Engl J Med 363: 711-723, 2010.

2 Topalian SL, Hodi FS, Brahmer JR, Gettinger SN, Smith DC, McDermott DF, Powderly JD, Carvajal RD, Sosman JA, Atkins MB, Leming PD, Spigel DR, Antonia SJ, Horn L, Drake CG, Pardoll DM, Chen L, Sharfman WH, Anders RA, Taube JM, McMiller TL, Xu H, Korman AJ, Jure-Kunkel M, Agrawal S, McDonald D, Kollia GD, Gupta A, Wigginton JM and Sznol M: Safety, activity, and immune correlates of anti-PD-1 antibody in cancer. N Engl J Med 366: 2443-2454, 2012.

3 Byun DJ, Wolchok JD, Rosenberg LM and Girotra M: Cancer immunotherapy - immune checkpoint blockade and associated endocrinopathies. Nat Rev Endocrinol 13: 195-207, 2017.

4 Shiba M, Inaba H, Ariyasu H, Kawai S, Inagaki Y, Matsuno S, Iwakura H, Yamamoto Y, Nishi M and Akamizu T: A case of fulminant type 1 diabetes mellitus accompanied by positive conversion of anti-insulin antibody after administration of antiCTLA-4 antibody after discontinuation of anti-PD-1 antibody Internal Medicine, 2018 in press.

5 Pearce EN, Farwell AP and Braverman LE: Thyroiditis. N Engl J Med 348: 2646-2655, 2003.

6 Ariyasu R, Horiike A, Yoshizawa T, Dotsu Y, Koyama J, Saiki M, Sonoda T, Nishikawa S, Kitazono S, Yanagitani N and Nishio M: Adrenal Insufficiency Related to Anti-Programmed Death-1 Therapy. Anticancer Res 37: 4229-4232, 2017.
7 Oda T, Sawada Y, Okada E, Yamaguchi T, Ohmori S, Haruyama $\mathrm{S}$, Yoshioka $\mathrm{M}$ and Nakamura $\mathrm{M}$ : Hypopituitarism and hypothyroidism following atrioventricular block during nivolumab treatment. J Dermatol 44: e144-e145, 2017.

8 Zeng MF, Chen L, Ye HY, Gong W, Zhou LN, Li YM and Zhao XL: Primary hypothyroidism and isolated ACTH deficiency induced by nivolumab therapy: Case report and review. Medicine (Baltimore) 96: e8426, 2017.

9 Caturegli P, Newschaffer C, Olivi A, Pomper MG, Burger PC and Rose NR: Autoimmune hypophysitis. Endocr Rev 26: 599614, 2005.

10 Okano Y, Satoh T, Horiguchi K, Toyoda M, Osaki A, Matsumoto S, Tomaru T, Nakajima Y, Ishii S, Ozawa A, Shibusawa N, Shimada T, Higuchi T, Chikamatsu $\mathrm{K}$ and Yamada $\mathrm{M}$ : Nivolumab-induced hypophysitis in a patient with advanced malignant melanoma. Endocr J 63: 905-912, 2016.

11 Caturegli P, Di Dalmazi G, Lombardi M, Grosso F, Larman HB, Larman T, Taverna G, Cosottini M and Lupi I: Hypophysitis Secondary to Cytotoxic T-Lymphocyte-Associated Protein 4 Blockade: Insights into Pathogenesis from an Autopsy Series. Am J Pathol 186: 3225-3235, 2016.

12 Hannon MJ and O'Halloran DJ: Isolated acquired ACTH deficiency and primary hypothyroidism: a short series and review. Pituitary 14: 358-361, 2011.

13 Kitajima K, Ashida K and Wada N: Isolated ACTH deficiency probably induced by autoimmune-related mechanism evoked with nivolumab. Jpn J Clin Oncol 47: 463-466, 2017.

14 Cho KY, Miyoshi H, Nakamura A, Kurita T and Atsumi T: Hyponatremia can be a powerful predictor of the development of isolated ACTH deficiency associated with nivolumab treatment Endocr J 64: 235-236, 2017.

15 Yamauchi I, Sakane Y, Fukuda Y, Fujii T, Taura D, Hirata M, Hirota K, Ueda Y, Kanai Y, Yamashita Y, Kondo E, Sone M, Yasoda A and Inagaki N: Clinical features of nivolumab-induced thyroiditis: a case series study. Thyroid 27: 894-901, 2017.

16 Bowyer S, Prithviraj P, Lorigan P, Larkin J, McArthur G, Atkinson V, Millward M, Khou M, Diem S, Ramanujam S, Kong B, Liniker E, Guminski A, Parente P, Andrews MC, Parakh S, Cebon J, Long GV, Carlino MS and Klein O: Efficacy and toxicity of treatment with the anti-CTLA-4 antibody ipilimumab in patients with metastatic melanoma after prior antiPD-1 therapy. Br J Cancer 114: 1084-1089, 2016.

17 Gebhardt C, Sevko A, Jiang H, Lichtenberger R, Reith M, Tarnanidis K, Holland-Letz T, Umansky L, Beckhove P, Sucker A, Schadendorf D, Utikal J and Umansky V: Myeloid cells and related chronic inflammatory factors as novel predictive markers in melanoma treatment with ipilimumab. Clin Cancer Res 21: 5453-5459, 2015. 